\title{
Characteristics of A New Reo-like Virus Isolated from Landlocked Salmon (Oncorhynchus masou Brevoort)
}

\author{
Ya-Li Hsu, Bor-Shiun CHEN, and Jen-Leih Wu \\ Institute of Zoology, Academia Sinica, Nankaang, Taipei, Taiwan, \\ 11529, R.O.C.
}

(Received November 14, 1988)

\begin{abstract}
A new reo-like virus was isolated from landlocked salmon around the Wu-Lin farm in the upper basin of Ta-Chia river, and designated as LSV (landlocked salmon virus). It has shown typical plaque-like syncytial CPE in tissue culture, and replicated very well in AS, BF-2, BB, CCO and CHSE-214 cell lines. But RTG-2 and TO-2 cells produced little virus. The optimal growth temperature of LSV in CHSE-214 is $20^{\circ} \mathrm{C}$. The typical double-layered capsid of icosahedral virion with a $78 \mathrm{~nm}$ diameter was shown in electron micrography. The buoyant density of LSV in $\mathrm{CsCl}$ is $1.365 \mathrm{~g} / \mathrm{ml}$. Those are typical characteristics of Reoviridae. However, LSV has 11 segmented ds RNA genomes and 5 major virion proteins, has aquatic animal hosts which are characteristics of aquareovirus, but is different from viruses of the defined six genera of Reoviridae. Compared to the electrophoretype of RNA genomes and virion proteins of LSV, CSV, CRV, GSV, and 13P2, the RNA pattern of LSV is closer to that of CSV, but the virion protein pattern is closer to that of 13P2. However, each aquareovirus has its own unique RNA and virion protein pattern. These results indicate that LSV is a newly discovered virus and the first aquareovirus isolated in Taiwan.
\end{abstract}

The landlocked salmon (Oncorhynchus masou BreVoort) was found near the Wu-Lin farm in the upper basin of Ta-Chia river of Taiwan. It was first described by a technician in Taiwan in 1917 (LIN, 1986). This species is now near extinction. In 1984, our government initiated a culture center and a program to protect the landlocked salmon. The artificial hatchery was started and supported by the Lu-Kung Fisheries branch in 1985 (Hsu et al., 1987). The mortality rate of these fries was then about $90 \%$. Most died in fry or egg stages. Our laboratory began to investigate the disease problem of the landlocked salmon in order to understand the reasons for the high mortality. Since regulations prohibit killing live fish of this species, we can only study the disease problem by using these moribund eggs and fish (Hsu et al., 1987). The overgrowth of intestinal bacteria and cytotoxicity of the dead bodies from moribund fish covered the pathogens, making study difficult. However, from 7 adult fish, 357 eggs and 193 fries, one reo-like virus was isolated from a $14.2 \mathrm{~cm}$ length fish. This isolate was designated landlocked salmon virus (LSV).
Nine reo-like viruses isolated from fish and shellfish have been reported; eight from the fish hosts, golden shiner (Notemigonus crysoleucas, Plumb et al., 1979), chum salmon (Oncorhynchus keta, Winton, 1981), channel catfish (Ictalurus punctatus, Hedrick et al., 1984), grass carp reovirus (Ctenopharyngodon idellus, CHEN \& JIANG, 1984a, b), tench (Tinca tinca, AHNE and Kolbl, 1987), chub (Leuciscus cephalus, AHNE and KolBL, 1987), fency carp (Cyprinus carpio, SANO and FuKUDA, 1987), Japanese eel (Anguilla japonica, Sano and FukUda, 1987) and one from the American oyster (Crassostrea virginica, MEYERS, 1979). These viruses were compared (WINTON et al., 1987). In this paper are described the characteristics of LSV as compared with the above mentioned 4 reolike viruses (CSV, GSV, CRV and 13P2) by their morphology, and an analysis of SDS-PAGE of the major virion protein and 11 segmented RNA genome patterns. The pathogenicity of LSV was also discussed. 


\section{Materials and Methods}

\section{Viruses}

Golden shiner virus (GSV), channel catfish reovirus (CRV), and American oyster virus (13p2) were kindly given by Dr. R. P. HEDRICK, University of California, Davis, U.S.A. and chum salmon virus (CSV) was given by Dr. J. R. Winton, National Fisheries Research Center, Seattle, WA. Landlocked salmon virus (LSV) isolated from diseased fish was plaque-purified three times prior to use in our morphologicaal and biochemical studies. Human reovirus type 3 (Dearing strain) was provided by Dr. C. S. Lai, National Taiwan University, Taipei, Taiwan, R.O.C.

\section{Cell lines}

CHSE-214 cells (Nims et al., 1970), BF-2 (WoLF and QuimBY, 1966), BB (Wolf and QuimBY, 1969), CCO (Bowser and Plumb, 1980), AS (Nicholson and BYrNe, 1973), EPC (TOMASEC and FiJAN, 1971), FHM (Gravell and MALSBERger, 1965), GK (Nicholson et al., 1987), MHR, PH, PL (NICHOLSON et al., 1987), RTG-2 (Wolf and QuimBY, 1962) and TO-2 (CHEN et al., 1983) were used to test the replication of LSV. CHSE-214 cells were used to propagate and assay the CSV, GSV, 13P2 and LSV isolates. The channel catfish ovary $(\mathrm{CCO})$ cells were used for the multiplication of CRV.

All cell lines were grown as monolayer cultures using minimum essential medium (MEM) with Earles' salts (Gibco) and 10\% (MEM-10) fetal calf serum (Flow lab., U.S.A.), $100 \mathrm{U} / \mathrm{m} l$ penicillin, $100 \mu \mathrm{g} / \mathrm{m} l$ streptomycin, $25 \mu \mathrm{g} / \mathrm{m} l$ gentamycin (Gibco), $2.5 \mu \mathrm{g} / \mathrm{m} l$ fungizone (Squibb and Sons Inc., USA) and $5 \mathrm{~m} l$ of $7.5 \% \mathrm{NaHCO}_{3}$. CHSE214 and $\mathrm{AS}$ were incubated at $20^{\circ} \mathrm{C}$, the other cell lines at $25^{\circ} \mathrm{C}$. Only TO-2 cells were cultured in L-15 medium.

\section{Virus Isolation}

The tissues of liver, kindey, spleen, pancreas, heart, and gill were homogenated in a polytron (Kine matica, Switzerland) with $10 \mathrm{vol}(\mathrm{V} / \mathrm{W})$ of MEM containing double strength antibiotics (WU et al., 1987). The homogenate was centrifuged and the supernatant was filtered and then inoculated onto the monolayers of BF-2, CCO, CHSE-214 and AS cell lines. The inoculated culture plates were examined daily. When extensive cytopathic effect was observed, the medium was filtered and infected again with a fresh culture.

\section{Virus assay}

The virus titers were determined by $\mathrm{TCID}_{50}$ in 96 well microplates (Greiner, W. Germany) and the endpoints were calculated according to REED and MuenCH (1938).

\section{Virus purification}

The virus purification procedure was adapted from a modified method described by WINTON et al. (1987). The harvested virus suspension was centrifuged at $100,000 \times g$ for $1 \mathrm{hr}$. The virus pellet was resuspended in SSC $(0.15 \mathrm{M}$-sodium chloride, 0.015 m-sodium citrate, $\mathrm{pH} 7.4$ ) and extracted with Freon 113 (1, 1, 2-trichloro-1, 2, 2-trifluoroethane). The aqueous phase was placed onto a continuous sucrose gradient (15 to $50 \%$ sucrose in SSC) and centrifuged at $100,000 \times$ $g$ for $2 \mathrm{hrs}$. The virus band was collected and loaded onto a three step $\mathrm{CsCl}$ gradient $(2.0 \mathrm{ml}$ of $40 \% \mathrm{CsCl}, 1.5 \mathrm{ml}$ of $30 \% \mathrm{CcCl}$, and $1.0 \mathrm{ml}$ of $20 \% \mathrm{CsCl}$ in SSC), and centrifuged at $115,000 \times \mathrm{g}$ for $16 \mathrm{hrs}$. The virus band was withdrawn and resuspended in SSC and pelleted by centrifugation at $115,000 \times g$ for $1 \mathrm{hr}$.

\section{Electron microscopy}

A drop of purified virus in distilled water was placed onto a Formvar coated grid. The unbuffered $2 \%$ phosphotungstic acid (adjusted with $\mathrm{NaOH}$ to pH 7.0) was added and stained for $1 \mathrm{~min}$. The excess solution was removed with a filter paper wedge and the virions were examined with a Hitach electron microscope.

\section{Density of virions}

Purified virus was placed onto the top of a three step $\mathrm{CsCl}$ gradient and centrifuged for $16 \mathrm{hrs}$ at $115,000 \times g$ at $4 \mathrm{C}$. Fractions were collected, and the density of each fraction was determined using an Abbe's refractometer (Bausch and Lomb).

\section{Viral RNA gel electrophoresis}

When extensive CPE was observed in the infected CHSE-214 cells of $25 \mathrm{~cm}^{2}$ flask (CCO for 


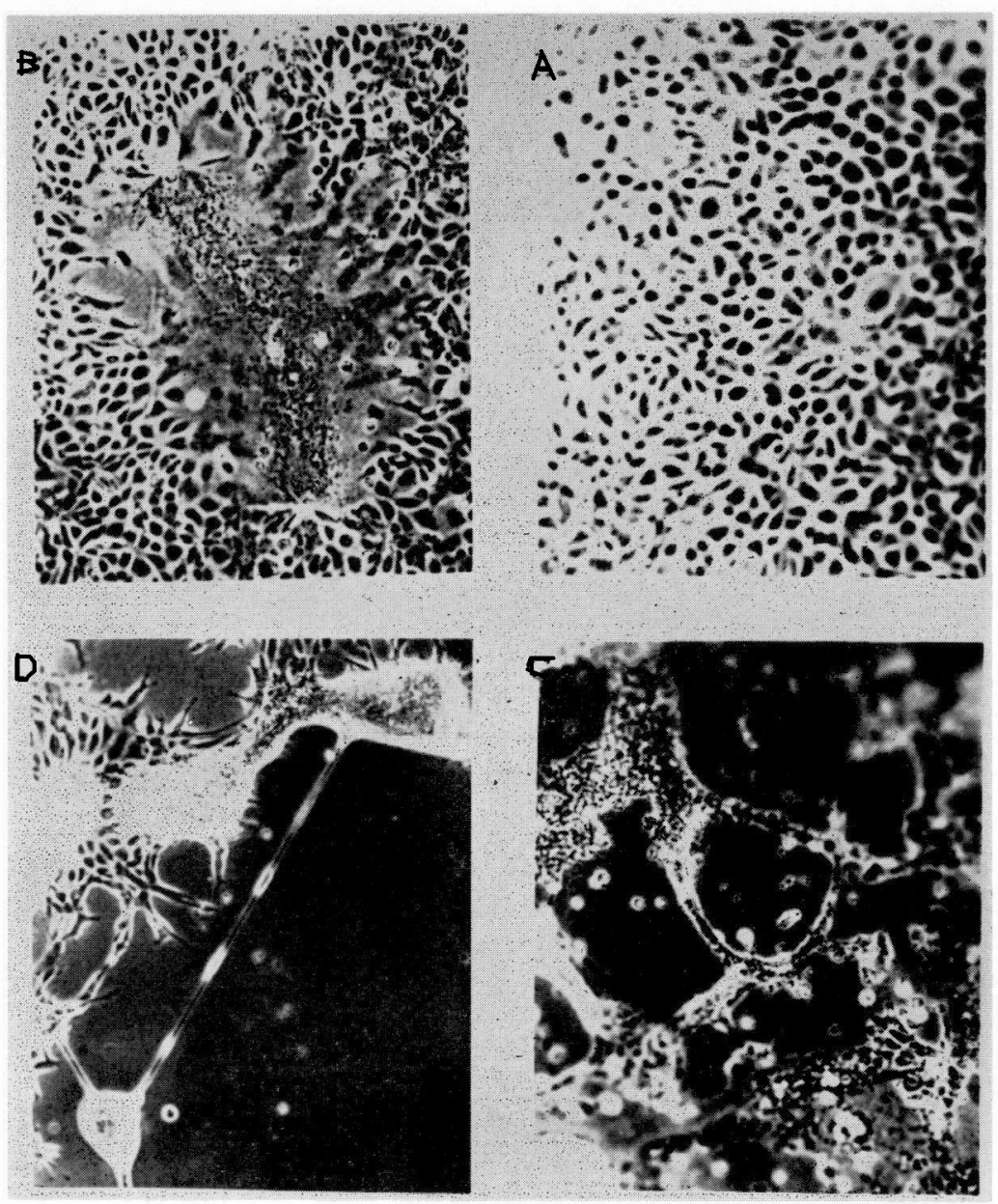

Fi0. 1. The cytopathic effect of LSV on the CHSE-214 cells. A. Normal CHSE-214 cells. B. The typical plaque-like syncytial CPE in CHSE-214 cells. C \& D. Extensive CPE of LSV in CHSE-214 cells.

CRV), the virus suspension was mixed with sarkosyl to a final concentration of $0.1 \%$ and centrifuged at $130,000 \times \mathrm{g}$ for $1 \mathrm{hr}$ at $4 \mathrm{C}$. The pellet was incubated with $0.5 \% \mathrm{SDS}$ and $200 \mu \mathrm{g} /$ $\mathrm{m} l$ proteinase $\mathrm{K}$ in a TNE buffer $(0.1 \mathrm{M}$ Tris, $0.1 \mathrm{~m} \mathrm{NaCl}, 1 \mathrm{~mm}$ EDTA, pH 7.3) at $37 \mathrm{C}$ overnight. Then an equal volume of $2 \times$ SDS sample buffer was added and boiled for $2 \mathrm{~min}$ (Hsu et al., 1988; HedRICK et al., 1983). For the RNA pattern, $10 \%$ polyacrylamide gel electrophoresis was used, and $5 \mathrm{~mA} /$ gel was conducted for $40 \mathrm{hrs}$. The gel was stained with silver nitrate.

Virion protein gel electrophoresis
Purified virus was mixed with protein sample buffer (Hsu, et al., 1985) and boiled for $3 \mathrm{~min}$, and applied onto the $10 \%$ SDS-polyacrylamide gel (LAEMMLI, 1970). After electrophoresis for $4 \mathrm{hrs}$ at $20 \mathrm{~mA}$, the gel was fixed and stained with silver nitrate (Hsu, et al., 1986).

\section{Silver stain}

The silver stain procedure for nucleic acid was modified from Goldman's and Guillemette's (Goldman et al., 1980; Guillemette and Lewis, 1983) methods. After electrophoresis for RNA, the gel was fixed in $50 \%$ methanol and $12 \%$ acetic acid for $3 \mathrm{~min}$. The SDS in the gel was removed 
Table 1. The multiplication of landlocked salmon virus (LSV) in selected fish cell lines at $18^{\circ} \mathrm{C}$

\begin{tabular}{lll}
\hline \multicolumn{1}{c}{ Cell line } & Abbreviation & TCID $_{50} / \mathrm{m}^{\prime}$ \\
\hline Atlantic salmon & AS & $2.2 \times 10^{5}$ \\
Bluegill fry & BF-2 & $7.0 \times 10^{8}$ \\
Brown bullhead & BB & $5.0 \times 10^{7}$ \\
Channel catfish ovary & CCO & $1.0 \times 10^{8}$ \\
Chinook salmon embryo & CHSE-214 & $1.0 \times 10^{7}$ \\
Epithelioma papillosum cyprini & EPC & $3.2 \times 10^{4}$ \\
Fathhead minnow & FHM & $5.0 \times 10^{3}$ \\
Grouper kidney & GK & $1.6 \times 10^{4}$ \\
Milkfish heart & MHR & $6.8 \times 10^{5}$ \\
Perch heart & PH & $6.8 \times 10^{4}$ \\
Perch liver & PL & $4.7 \times 10^{6}$ \\
Rainbow trout gonad & RTG-2 & $6.8 \times 10^{3}$ \\
Tilapia ovary & TO-2 & $3.2 \times 10^{2}$ \\
\hline
\end{tabular}

Table 2. Effect of temperature on landlocked salmon virus (LSV) multiplication in BF-2 cells

\begin{tabular}{cccccccc}
\hline \hline Temperature & $10^{\circ} \mathrm{C}$ & $15^{\circ} \mathrm{C}$ & $13^{\circ} \mathrm{C}$ & $20^{\circ} \mathrm{C}$ & $22^{\circ} \mathrm{C}$ & $25^{\circ} \mathrm{C}$ & $30^{\circ} \mathrm{C}$ \\
\hline $\mathrm{TCID}_{50} / \mathrm{ml}$ & $4.3 \times 10^{4}$ & $7.9 \times 10^{8}$ & $7.9 \times 10^{8}$ & $2.0 \times 10^{7}$ & $1.3 \times 10^{7}$ & $1.4 \times 10^{8}$ & $4.0 \times 10^{4}$ \\
\hline
\end{tabular}

by thrice washing with $10 \%(\mathrm{v} / \mathrm{v})$ ethanol and $5 \%(\mathrm{v} / \mathrm{v})$ acetic acid, each time for $10 \mathrm{~min}$. Then the gel was soaked in $0.1 \%$ CTAB (cetyltrimethylammonium bromide) for $30 \mathrm{~min}$, and washed with distilled water for $30 \mathrm{~min}$. The gel was changed into $0.3 \%$ ammonia and shaken for $15 \mathrm{~min}$. Then the ammoniacical silver solution $(1.6 \%$ silver nitrate, $0.12 \%$ ammonia, $4 \mathrm{~mm}$ $\mathrm{NaOH}$ ) was replaced and shaken for $15 \mathrm{~min}$. The gel was rinsed with distilled water within $15 \mathrm{sec}$. The developed solution (2\% sodium carbonate, $0.02 \%$ formaldehyde) was added quickly and shaken until the RNA band appeared. The development was stopped by adding $0.25 \%$ nitric acid for $15 \mathrm{~min}$, and then the gel was rinsed with water and dried for storage.

\section{Results}

\section{Virus isolation}

Only one virus was isolated from the liver and gills of one diseased fish. This fish showed necrosis of the pelvic fin and internal organs (Hsu, et al., 1978). After inoculation of tissue homogenate on different monolayers, such as AS, BF2, CCO, and CHSE-214, these cells were incubated at $20 \mathrm{C}$ or $25^{\circ} \mathrm{C}$. After 14 hays postinoculation, the typical cytopathic effect of these cells showed the plaque-like syncytia. The fusion and lysis of these cells became more serious at longer period of incubation (Fig. 1). This reo-like virus isolate was designated landlocked salmon virus (LSV).

\section{Host range}

After three consecutive plaque assays, the LSV virus was cultured, and the host range of LSV was determined by 13 fish cell lines. The results are shown in Table 1. LSV replicated very well in AS, BF-2, BB, CCO, and CHSE-214 cell lines. Limited replication occurred in EPC, FHM, GK, MHR, PH and PL cells, while RTG-2 and TO-2 were refractory to produce $\mathrm{CPE}$ and little virus. LSV cannot replicate in BHK-21 mammalian cells and human reovirus (type 3 ) can not replicate in CHSE-214 fish cells.

\section{Optimal growth temperature}

Virus fluid $(0.5 \mathrm{ml})$ with $10 \mathrm{TCID}_{50}$ was separately placed onto a monolayer of BF-2 cells in $25 \mathrm{~cm}^{2}$ flasks. Two flask were incubated at each temperature; at $10,15,18,20,22,25$ and $30^{\circ} \mathrm{C}$. When extensive CPE was observed, the virus suspension was centrifuged and the supernatant was titrated by TCID $_{50}$ method (REED and MUENCH, 1938). The results are shown in Table 2 and Fig. 2. The optimal temperature for LSV multiplication was 


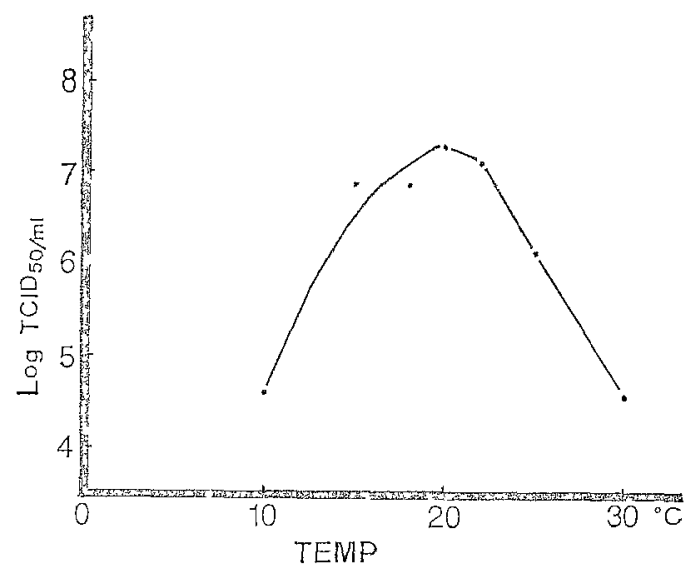

Fig. 2. Effect of temperature on the multiplication of LSV in BF-2 cells.

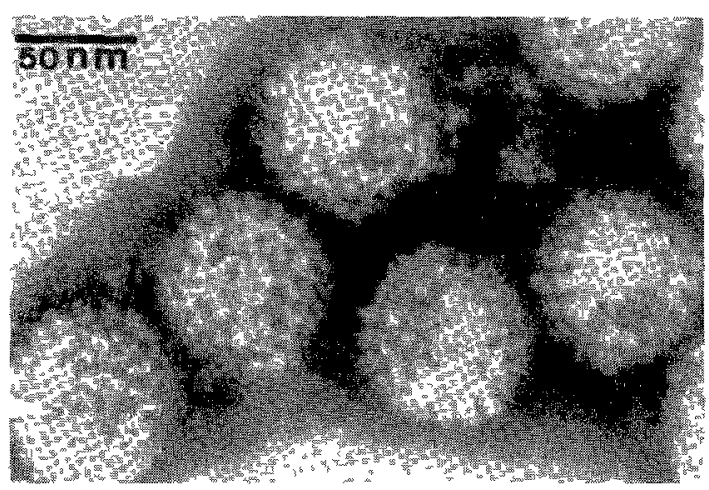

Fig. 3, Electron micrography of negatively stained LSV

$20^{\circ} \mathrm{C}$ LSV can replicate very well in 15 to $25^{\circ} \mathrm{C}$, but not at 10 or $30^{\circ} \mathrm{C}$

\section{Virlon density and morphology}

After centrufugation in $\mathrm{CsCl}$ gradient, the virus band was collected, and the buoyant density of the complete particles was measured in $\mathrm{CsCl}$, and found to be $1.365 \mathrm{~g} / \mathrm{mol}$. The purffed virus was negatively stained, and under EM observation, the virions revealed particles with icosahedral symmetry and a double capsid shell of about $78 \mathrm{~nm}$ mean diameter (F1g 3). Twenty perupheral capsomeres were present around the periphery of the outer capsid shell. These morphological features are characteristics of members of the Reoviridae.

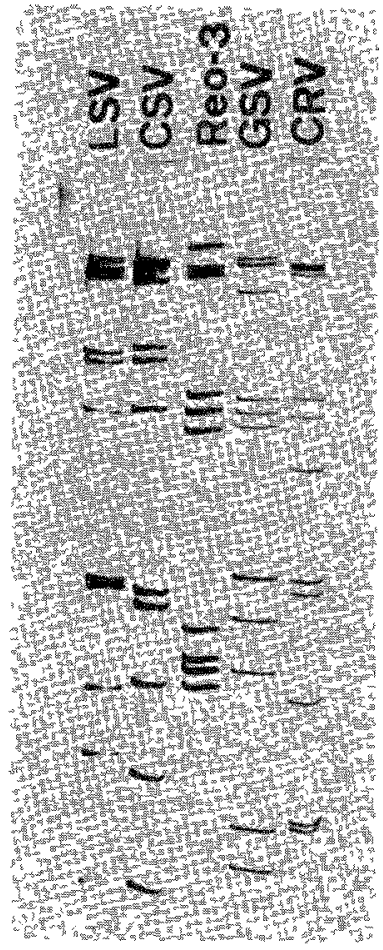

Fig. 4. Electrophoretypes of RNA genomes of LSV, CSV, Reo-3, GSV and CRV

\section{SDS-PAGE analysts of RNA genome}

Electrophoresis of RNA genome by using 10\% SDS-PAGE, this silver-stained gel revealed that each of the aquareoviruses, LSV, CSV, GSV and CRV, had a genome composed of 11- segmented ds RNA ( $F_{1} g$ 4). The molecular weight of all these RNA segments fell into three size classes that ranged from $25 \times 10^{6}$ to $0.31 \times 10^{6}$ daltons (Table 3) There were three large (L1, L2, and L3), three medium (M1, M2, and M3), and five small segments ( 1, S2, S3, S4, and S5) in each genome (F1g 4) (Winton et al., 1983). However, reovirus type 3 (Reo-3 in Fig. 4) was quite different; it had four instead of five small RNA segments. Each aquareovirus had its own unique RNA electrophoretype (Fig 4), but the the total genome of each was approximately $15 \times 10^{8}$ daltons, which was consistent with the values of other reoviruses However, the RNA patterns of these aquareoviruses were unlike those reported for members of the six genera currently defined with the Reoviridae (JoKL.IK, 1981, 1983a; 1983b; WINTON, et al, 1987). 
Table 3. Estimates of molecular weight of RNA segments of five reoviruses from aquatic animals compared to reovirus type $3\left(\mathrm{MW} \times 10^{-6}\right)$

\begin{tabular}{ccccccc}
\hline \hline & \multicolumn{7}{c}{ RNA molecular weight $\left(\times 10^{-6}\right)$} & & \\
Segment & $13 P 2^{*}$ & CSV & LSV & GSV & CRV & Reo-3 \\
L1 & 2.40 & 2.40 & 2.50 & 2.50 & 2.40 & 2.50 \\
L2 & 2.30 & 2.40 & 2.40 & 2.40 & 2.40 & 2.40 \\
L3 & 2.30 & 2.30 & 2.35 & 2.20 & 2.30 & 2.30 \\
M1 & 1.90 & 1.80 & 1.75 & 1.60 & 1.60 & 1.60 \\
M2 & 1.70 & 1.70 & 1.70 & 1.50 & 1.50 & 1.60 \\
M3 & 1.40 & 1.50 & 1.50 & 1.40 & 1.30 & 1.40 \\
S1 & 0.85 & 0.88 & 0.90 & 0.90 & 0.90 & 0.92 \\
S2 & 0.80 & 0.85 & 0.89 & 0.80 & 0.88 & 0.76 \\
S2 & 0.57 & 0.61 & 0.60 & 0.66 & 0.61 & 0.64 \\
S4 & 0.47 & 0.47 & 0.50 & 0.40 & 0.41 & 0.61 \\
S5 & 0.35 & 0.31 & 0.31 & 0.35 & 0.40 & none \\
Total & 15.04 & 15.22 & 15.71 & 14.71 & 14.70 & 14.93 \\
\hline
\end{tabular}

* From Winton et al. (1987).

Table 4. Estimates of molecular weight of the major structural virion proteins of five reoviruses from aquatic animals

\begin{tabular}{cccccc}
\hline \hline \multirow{2}{*}{ Polypeptide } & \multicolumn{5}{c}{$\left(\right.$ M.W. $\left.\times 10^{-3}\right)$} \\
\cline { 2 - 6 } & LSV & 13 P2 & CSV & GSV & CRV \\
\hline$\lambda_{1}$ & 139 & 135 & 137 & 137 & 132 \\
$\lambda_{2}$ & 130 & 128 & 126 & 130 & 130 \\
$\mu_{1}$ & 69 & 70 & 68 & 63 & 70 \\
$\sigma_{1}$ & 44 & 45 & 45 & 43 & 43 \\
$\sigma_{2}$ & 34 & 33 & 33 & 36 & 32 \\
\hline
\end{tabular}

The RNA pattern of LSV was closer to that of CSV, but quite different. The major difference between RNA segments of LSV and CSV was in S1, S2, and S3 (Fig. 4). Compared with the estimated molecular weight of each RNA of aquareovirus, including 13P2 (WINTON et al., 1987) (Table 3), we found that each virus had a unique pattern, which indicated that LSV was a new aquareovirus.

\section{SDS-PAGE analysis of virion polypeptides}

A comparison of virion proteins of LSV, CSV, CRV, GSV and 13P2 was made by silver-stained $10 \%$ SDS-PAGE as shown in Fig. 5. The estimated molecular weight of each polypeptide is listed in Table 4. These aquareoviruses had two large $\left(\lambda_{1}\right.$ and $\left.\lambda_{2}\right)$, one medium $\left(\mu_{1}\right)$ and two small virion proteins ( $\sigma_{1}$ and $\sigma_{2}$ ) ranging from 139,000 to 32,000 . According to Fig. 5, the peptide pattern of LSV was closer to that of

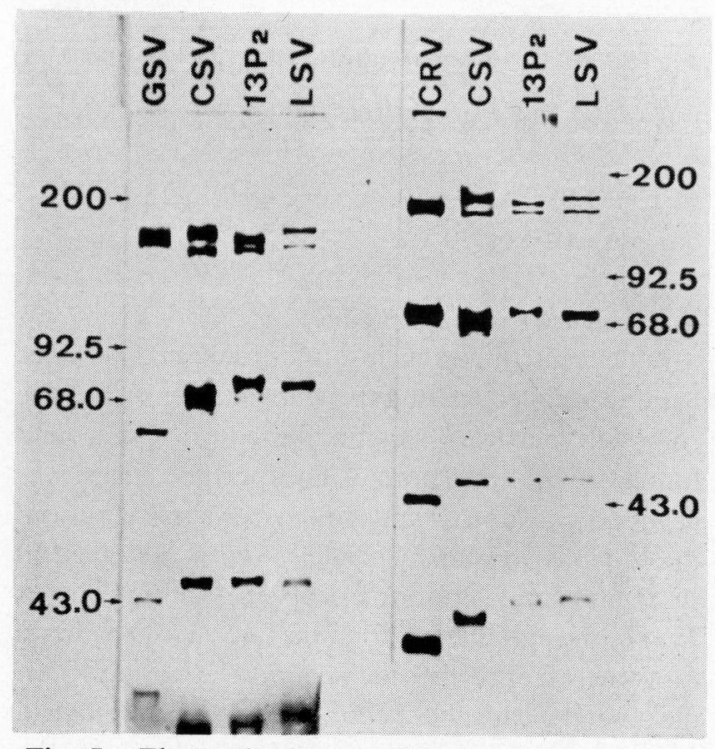

Fig. 5. Electrophoretypes of major virion proteins of CSV, CRV, GSV, 13P2, and LSV. 
13P2, but their $\mu_{1}, \lambda_{1}$ and $\lambda_{2}$ were lightly different (Table 4). The virion protein pattern of LSV was unique and different from that of CSV, GSV, CRV and 13P2. This was another index that LSV was a new aquareovirus isloate.

\section{Discussion}

The first reo-like virus isolated from golden shiner (GSV) was reported by Plumb et al. (1979). Schwedler and Plumb (1980) indicated that this GSV was clearly different from the birnaviruses both in particle morphology and serological characteristics. In 1981, WINTON et al. also described a chum salmon virus (CSV) that shared physical properties with GSV, suggesting the two viruses were related, and also revealed that CSV contained 11 segments of ds RNA (WINTON et al., 1983). AMEND et al. in 1984 reported that a channel catfish virus (CRV) shares physical and morphological properties with both GSV and CSV and that the antisera of CRV also neutralizes CSV and GSV. In 1987, WINTON et al. compared the morphological and biochemical properties of these four reo-like viruses (CSV, CRV, GSV and 13P2) isolated from aquatic animals, and indicated that these viruses with common characters should be categorized to as a common group. Chen and JiAng in 1984 (a and b) desecribed and characterized a virus isolated from the hemorrhagic grass carp and identified this virus as a reovirus which was tentatively designated as herpesvirus of grass carp in 1980. SANO and FuKUDA indicated reo-like viruses have been isolated from fancy carp and Japanese eel from Tokyo university of Fisheries in 1987. At the same year, Ahne and Kolbl reported that two viruses have been isolated from tench (Tinca tinca) and chub (Leuciscus cephalus). They have a double capsid and a size of $70-75 \mathrm{~nm}$ with a 11 segments of ds RNA genome.

In our laboratory, a routine rapid RNA gel electrophoresis was analyzed for confirmation and epizootiological studies of IPNV isolates. When a typical plaque-like syncytial CPE of a isolate appeared and its RNA patterns showed a reo-like virus, we started to culture this LSV in Baby hamster kidney (BHK-21) mammalian cells, and none of them grew. At the same time, we cultured human reovirus type 3 in CHSE-214 fish cell line. It also failed. From these results, we know that LSV and Reo-3 have quite different host and multiplication temperatures. However, LSV have 11 segments of ds RNA and $78 \mathrm{~nm}$ diameter icosahedron with double-layered capsid which expresses a typical reo-like virus. Compared to the electrophoretype of RNA and virion protein patterns of LSV with those of CSV, CRV, GSV and 13P2 (Figs. 4, 5, and Tables 3 and 4), it is obvious that each aquareovirus had a unique RNA and protein pattern. The RNA pattern of LSV is closer to that of CSV than of 13P2, and the virion protein pattern is closer to that of 13P2. These results indicated that LSV is a new isolate of aquareovirus. However, given such a low frequency of viral isolation and slow cytopathic effect in tissue culture, it seems reasonable to conclude that LSV is not a contagious and virulent pathogen for landlocked salmon. But it must widesperad enough in aquatic animals that we should screen this aquareovirus carefully. Recently, our laboratory also obtained one isolate from rainbow trout and one from hard clam, only the culture pond of hard clam had mortality (data not shown). This is correlated with the reports that the pathogenicity of these aquareoviruses except for the 13P2 virus (MEYERS, 1980) in fish is relatively low.

Matthews (1982) described that the Reoviridae family is composed of viruses with 10 to 12 segments of ds RNA and double-layered icosahedral virion. JoKLIK (1983a) also used genome numbers, particle structure, host range, and sensitivity to physical and chemical treatements to categorize the Reoviridae into six genera. Genus Orthoreovirus, Fijivirus, Orbivirus and Cypovirus have 10 segments of ds RNA; Phytoreovirus have 12 segments of ds RNA. Only Rotavirus has 11 segments of ds RNA. However, the viruses compared in this study showed electrophoretypes of RNA different from that of Rotavirus, and they have different aquatic animal hosts. In addition, Rotavirus RNA revealed no detectable homology with P-labelled CSV probe at $50 \%$ stringency (WINTON et al., 1987). Serological test revealed that the infectivity of CSV could not be neutralized by antisera against the three mammalian reovirus serotypes (WINTON, 1981) and that 13P2 could not be neutralized by antisera against Feline reovirus 
type 3, canine reovirus type 1 or chicken FDO reovirus (MEYERs, 1979). Based on the host range, optimal growth temperature, RNA segment patterns, and serological tests, the viruses in this study should be categorized as Reoviridae but probably in different genera aquareovirus.

\section{Acknowledgements}

We wish to thank Dr. R. P. Hedrick and Dr. J. R. Winton for sending isolates of aquareoviruses. This work was supported by a grant from the National Science Council (NSC-77-0211B001-39), and the Council of Agriculture (7711.2-Forestry-22(4)).

\section{References}

Ahne, W. and O. Kolbl (1987): Occurrence of reoviruses in European cyprinid fishes (Tinca tinca Lin.; Leuciscus cephalus Lin.) J. Appl. Ichthyol., 3, 139-141.

Amend, D. F., T. McDowell and R. P. Hedrick (1984): Characteristic of a previously unidentified virus from channel catfish (Ictalurus punctatus). Can. J. Fish. \& Aqua. Sci., 41, 807-811.

Bowser, P. R. and J. A. Plumb (1980): Crowth rates of a new cell line from channel catfish ovary and channel catfish virus replication at different temperatures. Can. J. Fish. Aqua. Sci. 37, 871-873.

Chen, S. N., S. C. Chi, Y. Ueno and G. H. Kou. (1983): A cell line derived from tilapia ovary. Fish Path., 18, 13-18.

CHEN, Y. and JiAng (1984a): Morphological and Physico-chemical characterization of the hemorrhagic virus of grass carp. Kexue Tongbao, 29, 832-835.

Chen, Y. and Jiang (1984b). Morphological physicochemical characterization of the hemorrhagic virus of grass carp. Sixth International Congress of Virology. Abstracts W37-1, pp. 373.

Goldman, D., S. A. Sedman and M. H. Ebbert (1980): Ultrasensitive stain for proteins in polyacrylamide gels shows regional variation in cerebrospinal fluid protiens. Science, 211, 1437-1438.

Gravell, M., and R. G. Malsberger (1965): A permanent cell line from the fathead minnow (Pimephales promelas). Ann. N. Y. Acad. Sci., 126, 555565.

Guillemette, J. G. and P. N. Lewis (1983): Detection of subnanogram quantities of DNA and RNA on native and denaturing polyacrylamide and agarose gels by silver staining. Electrophoresis. 4, 92-94.
Hedrick, R. P., J. L. Fryer, S. N. Chen and G. H. Kou (1983): Characteristics of four Birnaviruses isolated from fish in Taiwan. Fish Pathol., 18(2), 91-97.

Hedrick, R. P., R. Rosemark, D. Aroustein, J. R. Winton, T. MCcDowell and D. F. AMEND (1984): Characteristics of a new reovirus from channel catfish (Ictalurus punctatus). J. Gen. Virol., 65, 1527-1534.

Hsu, Y. L., B. S. Chen and J. L. Wu (1988). The comparison of RNA and protein gel patterns of Infectious pancreatic necrosis virus from eel and rainbow trout. J. Gen. Virol. (submitted).

Hsu, Y. L., B. S. Chen, C. Y. ChIEN, J. L. Wu, Y. S. Chow, and K.S. Chang. (1987): The study of fungi, bacteria and viruses of Oncorhynchus masou (Brevoort) I. Annual report of Ecology. no. 009, $18 \mathrm{pp}$.

Hsu, Y. L., H. M. ENGelKING, and J. C. LeONG. (1986): Occurrence of different types of infectious hematopoietic necrosis virus in Fish. Appl. Environ. Microbiol., 52, 1353-1361.

Hsu, Y. L., H. M. Engelking, and J. C. LeONG. (1985): Analysis of the quantity and synthesis of the virion protiens of infectious hematopoietic necrosis virus. Fish Path., 20, 331-338.

JoKLIK, W. K. (1981): Structure and function of the reovirus genome. Microbiol. Reviews, 45, 483-501.

Joklik, W. K. (1983a): The members of the family Reoviridae. In "The Reoviridae", ed. W. K. Joklik, N. Y. Plenum Press, pp. 1-7.

JokLIK, W. K. (1983b): The reovirus particle. In "The Reoviridae", ed. W. K. Joklik, N. Y. Plenum Press, pp. 9-78.

LAEMMLI, U. K. (1970): Cleavage of structural proteins during the assembly of the head of bacteriophage T4, Nature, 227, 680-685.

LIN, Yao-Sung (1986): Landlocked salmon in Taiwan highland. In: Memoir of Nature, Endangered and Rare plant/Animal species and landscape conservation (II). COA Forestry Series No. 9, p. 1-13.

Matthews, R. E. F. (1982): Classification and nomemclature of viruses. Intervirology, 17, 1-199.

MEYERS, T. R. (1979): A reo-like virus isolated from juvenile American oysters (Crassostrea virginica). $J$. Gen. Virol., 43, 203-212.

Meyers, T. R. (1980): Experimental pathogenicity of reovirus 13P2 in juvenile American oysters (Crassostrea virginica) (Gmelin) and in bluegill fingerlings (Lepomis macrochirus) (Rafinesque). J. Fish Dis., 3, 187-201.

Nicholson, B. L. and C. Byrne (1973): An established cell line from the Atlantic salmon (Salmo salar). J. Fish. Res. Board Can., 30, 913-916.

Nicholson, B. L., D. J. DANNER and J. L. Wu. (1987): 
Three new continuous cell lines from marine fishes of Asia. In Vitro, 23, 199-204.

Nims, L., J. L. Fryer and K. S. Pilcher (1970): Studies of replication of four selected viruses in two cell lines derived from salmonid fish. Proc. Soc. Exp. Biol. Med., 135, 6-12.

Plumb, J. A., P. R. Bowser, J. M. Grizzle and A. J. Mitchell. (1979): Fish viruses: A double-stranded RNA icosahedral virus from a North American cyprinid. J. Fish. Res. Board Can. 36, 1390-1394.

ReED, L. J. and H. Muench (1938): A simple method of estimating fifty percent endpoints. Amer. J. Hyg., 27, 493-497.

Sano, T. and H. Fukuda (1987): Principal Microbial diseases of mariculture in Japan. Aquaculture, 67, 59-69.

Schwedler, T. E., and J. A. Plumb (1980): Fish viruses: Serological comparison of golden shiner and infectious pencreatic necrosis viruses. J. Wildlife Dis., 16, 597-599.

Tomasec, J. and N. FiJAN (1971): Virusne balesti riba (viral diseases of fish). Final report on research under a part of project, $6 \mathrm{n} / 1966$, Zagreb.

Winton, J. R. (1981): Isolation and characterization of a new reovirus from chum salmon (Oncorhynchus keta). Ph. D. Thesis, Oregon State University. Winton, J. R., C. N. LANNAN and J. L. Fryer (1983): Further characterization of a new reovirus of poikilothermic vertebrates. In "Double-stranded RNA viruses”, pp. 231-236, ed. R. W. Compans and D. H. L. Bishop, N. Y. Elsevier.

Winton, J. R., C. N. Lannan, J. L. Fryer, R. P. Hedrick, T. R. Meyers, J. A. Plumb, and T. Yamaмото (1987): Morphological and Biochemical properties of four members of a novel group of reoviruses isolated from aquatic animals. J. Gen. Virol., 68 , 353-364.

Wolf, K. and M. C. Quimby (1962): Established eurythermic line of fish cells in vitro. Science, 135, 1065-1066.

Wolf, K., M. C. QuimBY (1966): Lymphocystis virus: isolation and propagation in centrarchid fish cell lines. Science, 151, 1004-1005.

Wolf, K., and M. C. Quimby (1969): Fish cell and tissue culture. pp. 253-305, In "Fish Physiology" ed. W. S. Hoar \& D. J. Randall, Academic Press. Wu, J. L., C. Y. Chang and Y. L. Hsu (1987): Characteristics of infectious pancreatic necrosis like virus isolated from Japanese eel (Anguilla japonica). Bull. Inst. Zool. Academia Sinica, 26, 201-214. 